\title{
Inauguration of the GSSP for the Jurassic System
}

\author{
Le Chardon, Quartier Brugière, 07200 Vogüé, France. E-mail nicol.morton@orange.fr
}

Formal definition of the Triassic-Jurassic boundary at a Global Stratotype Section and Point (GSSP) for the base of the Jurassic System proved to be difficult because of several geological factors. These include a major extinction event, a major global sea-level fall and the palaeogeographical and palaeoecological consequences of widespread tectonic and volcanic events. Historically the position of the boundary has been controversial. In 1984 the International Subcommission on Jurassic Stratigraphy (ISJS) set up a Working Group to investigate and document possible candidate sites and eventually select one to be proposed to ISJS as GSSP. At the end of the process six proposals, involving five sections and four possible key marker events were assessed and voted on by the members of the Working Group between February and April 2008. The Kuhjoch section in Austria, with key marker event the first occurrence of the ammonite Psiloceras spelae tirolicum, was proposed to ISJS. The proposal was accepted by ISJS in June 2008, by the International Commission on Stratigraphy in May 2009 and ratified by IUGS in April 2010. In August 2011 the GSSP was formally inaugurated during a ceremony on site by the placing of a permanent marker, the "golden spike".

\section{Introduction}

The Triassic/Jurassic boundary is the second last of the System boundaries to be defined formally by reference to a Global Stratotype Section and Point (GSSP), having been ratified by the Executive of IUGS in April 2010. This GSSP also defines the Lower Jurassic Series and the (basal) Hettangian Stage. At this time (January 2012), the only remaining System boundary not to have a GSSP selected is the Jurassic/Cretaceous.

Given the long history of research on the Jurassic and its key role in the development of the science and methodology of stratigraphy, this may seem surprising. However, there are special circumstances that help explain the situation. In Jurassic stratigraphy one fossil group - the ammonites - has a pre-eminent role in correlation and in (relative) dating of strata. For the Jurassic/Cretaceous boundary (technically the base of the Cretaceous) the ammonites display extreme faunal provincialisation, related to major sea-level and palaeogeographic changes. These cause difficulties of wider correlation that have not (until now) been resolved. The problem is currently being investigated and some progress has been made, partly by integrating also other dating and correlation techniques.

During the Triassic/Jurassic boundary interval there was a major extinction event (that almost resulted in the demise of the ammonoids) associated with a large global sea-level fall, tectonic and volcanic events. As a result there are very few sections with a continuous sequence of marine strata containing key fossils. From a historical perspective, in the geologically classic areas of NW Europe there was a major palaeogeographic change from predominantly continental non-marine sedimentation in the Triassic to mainly marine environments in the Jurassic.

\section{Background}

The degree of uncertainty about the Triassic/Jurassic boundary can be illustrated by reference to the Rhaetian Stage, variously placed in the Triassic or the Jurassic - compare, for example, the classic and influential works of W.J.Arkell. In his earlier review (Arkell 1933) of the Jurassic of Britain, the Rhaetian (White Lias etc.) was included in the Jurassic because it is marine or marginal-marine. However, with a broader perspective in his later review (Arkell 1956) of the Jurassic of the World the Rhaetian was placed in the Triassic because the faunas are of Triassic character, for example ceratites rather than ammonites (sensu.sticto).

Serious investigation and the search for a definition of the base of the Jurassic began with the establishment by the International Subcommission on Jurassic Stratigraphy (ISJS) of a Triassic/Jurassic Boundary Working Group in 1984, with Convenors René Mouterde (1984-2000) and Geoffrey Warrington (2000-2012) and Secretaries Jean Guex (1984-1993), Geoffrey Warrington (1993-2000) and Gert Bloos (2000-2008). Their work provided a framework and a list of criteria for the proposal and selection of candidate sections (see Working Group reports in the ISJS Newsletters, available for free download from the ISJS website at http://jurassic.earth. ox.ac.uk/).

The geological and palaeontological complexity of the Triassic/ Jurassic boundary interval is reflected by the approval and funding of IGCP Project 458 Triassic-Jurassic Boundary Events (2001-2006), with Co-Leaders Jozsef Palfy, Stephen Hesselbo and Christopher McRoberts. This project contributed a vast amount of information and new ideas on recognising, correlating and defining the boundary. For an introductory summary of the scope of the project see Hesselbo, McRoberts and Palfy (2007).

\section{A GSSP to define the boundary}

\section{GSSP Proposals}

By the time of the $7^{\text {th }}$ International Congress on the Jurassic System in Krakow, Poland, in September 2006, most of the relevant data had become available and the way forward was discussed during 
a special meeting of the Triassic/Jurassic Boundary Working Group. There were two surprises:

1. In 2005 a new section with the key basal Jurassic ammonites was discovered in Austria; some data were preliminary but completed by further work over the next two years;

2. In 2006 the Larne sections in Northern Ireland were rediscovered with important new data on the ammonites, but limited direct information on other aspects.

It was agreed that new or revised versions of proposals for all sections to be considered as GSSP candidates should be prepared and submitted to members of the Working Group. Decisions could not be made during a meeting, but must be by mail (nearly all by email) so that all members can participate.

Six proposals were considered by members of the Working Group. These are available in ISJS Newsletters 34 Part 1 (Bown, Morton and Lees 2007) and 35 Part 1 (Morton \& Hesselbo 2008):

1. St. Audrie's Bay section, Somerset, England, UK by G. Warrington, J.C.W. Cope \& H.C. Ivimey-Cook, primary marker the first occurrence of the ammonite Psiloceras planorbis;

2. Ferguson Hill section, New York Canyon, Nevada, USA by S.G. Lucas, D.G. Taylor, J. Guex, L.H. Tanner \& K. Krainer, primary marker the first occurrence of the ammonite Psiloceras spelae spelae;

3. Kunga Island section, Queen Charlotte Islands, British Columbia, Canada by L.M. Longridge, E.M. Carter, J.W. Haggart \& P.L. Smith, primary marker a major evolutionary change of radiolarian faunas;

4. Ferguson Hill section, New York Canyon, Nevada, USA by C.A. McRoberts, P.D. Ward \& S.P. Hesselbo, with primary marker a large negative carbon isotope excursion;

5. Kuhjoch section, Karwendel Mountains, Northern Calcareous Alps, Tyrol, Austria by A. von Hillebrandt, L. Krystyn \& W.M. Kuerschner, with primary marker the first occurrence of the ammonite Psiloceras spelae tirolicum;

6. Waterloo Bay section, Larne, Northern Ireland, UK by M.J. Simms and A.J. Jeram, with primary marker the first occurrence of the ammonite Psiloceras planorbis.

\section{Selection of GSSP}

It was generally agreed that none of the sections was ideal in fulfilling all the criteria proposed by the Working Group for the GSSP, but that these were the best likely to be available in the foreseeable future. A large amount of discussion was either posted on a special website (arranged by Chris McRoberts and password protected to members of the Working Group) or circulated by email to all Working Group members.

Voting was carried out in two stages - first was selection of primary marker, then second selection of preferred section demonstrating this key marker. The preferred primary marker was the first occurrence of the ammonite Psiloceras spelae (both subspecies spelae and tirolicum) (Hillebrandt \& Krystyn (2009). The preferred section was the Kuhjoch section in Austria (Fig. 1). A third vote, to confirm support for the Kuhjoch section as GSSP for the base of the Jurassic System was supported by $78.7 \%$ of the 61 Working Group members who voted.

The proposal, amended in the light of comments received, was forwarded to the Voting Members of the Jurassic Subcommission and supported by $66.7 \%$ in June 2008. After further modifications, reflecting comments received and further research, the proposal was approved by the International Commission on Stratigraphy (94\% of votes) in May 2009 and ratified by the Executive of IUGS in April 2010 .

\section{Inauguration of the GSSP - Inserting the "Golden Spike"}

The International Commission on Stratigraphy (ICS) has encouraged the physical marking of ratified GSSPs by the placing in the relevant outcrop of a permanent plaque or other marker (the "Golden Spike") and encourages the siting nearby of public information panels describing the section and explaining the significance of the site. To date over 60 have been placed.

The GSSP for the base of the Jurassic System, the Lower Jurassic Series and the Hettangian Stage in the Kuhjoch section, Karwendel National Park, Tyrol, Austria was formally inaugurated on 20th August 2011 at ceremonies on the site in the morning (Fig. 2) and in the Naturparkhaus Hinteriss (Fig.3) in the afternoon, organised by Sylvain Richoz, Graz, Austria. The meetings were sponsored by the Austrian Commission on Stratigraphy, the Austrian National Committee for Earth Sciences, the IGC Programme at the Austrian Academy of Science and the Natural Park Karwendel.

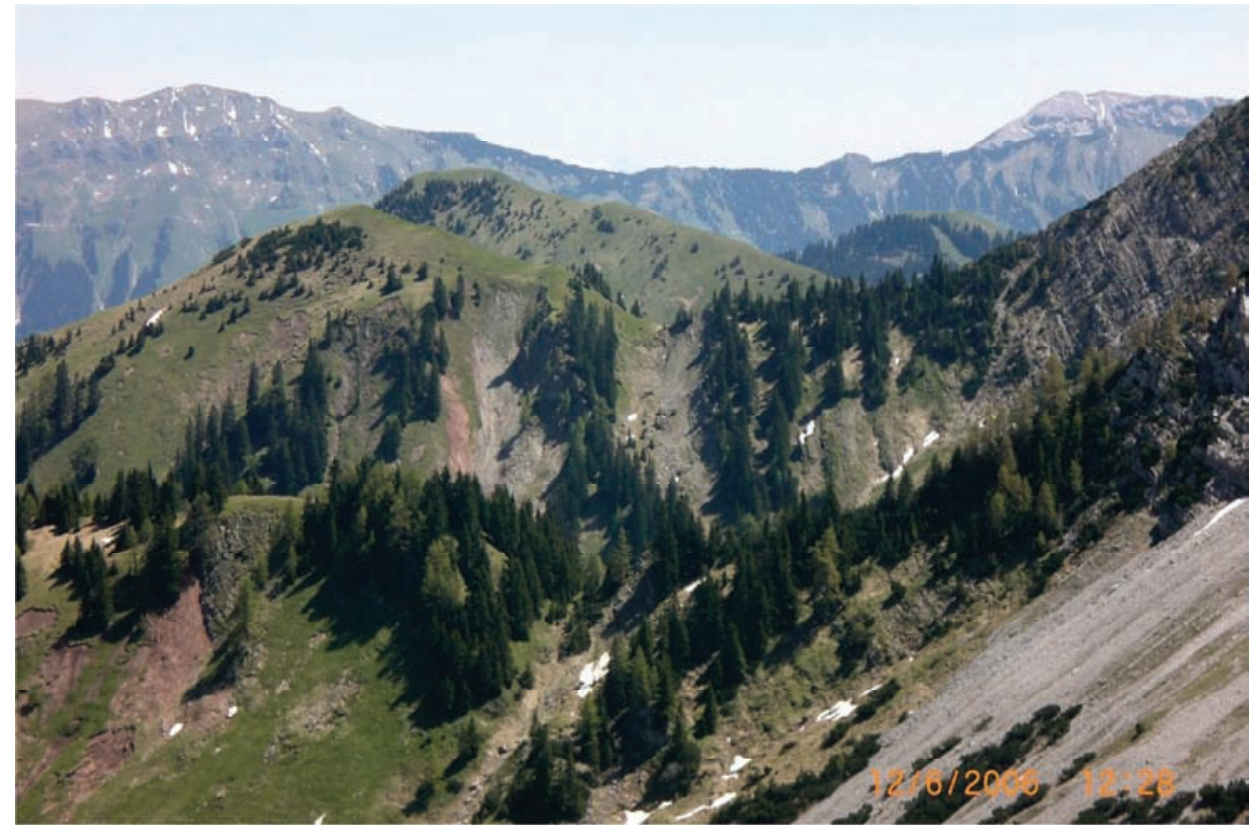

Figure 1. View from west of Ochsentaljoch (foreground) and Kuhjoch (middle ground) with other ridges to the east in the background, Karwendel Mountains, Tyrol, Austria. The Jurassic GSSP is situated on the crest of the lowest part of the Kuhjoch ridge. Note that the topographic feature associated with the Triassic-Jurassic boundary beds can be traced from Kuhjoch to Ochsentaljoch, with Upper Triassic carbonates to the right and Lower Jurassic carbonates to the left (photo Axel von Hillebrandt June 2006). 


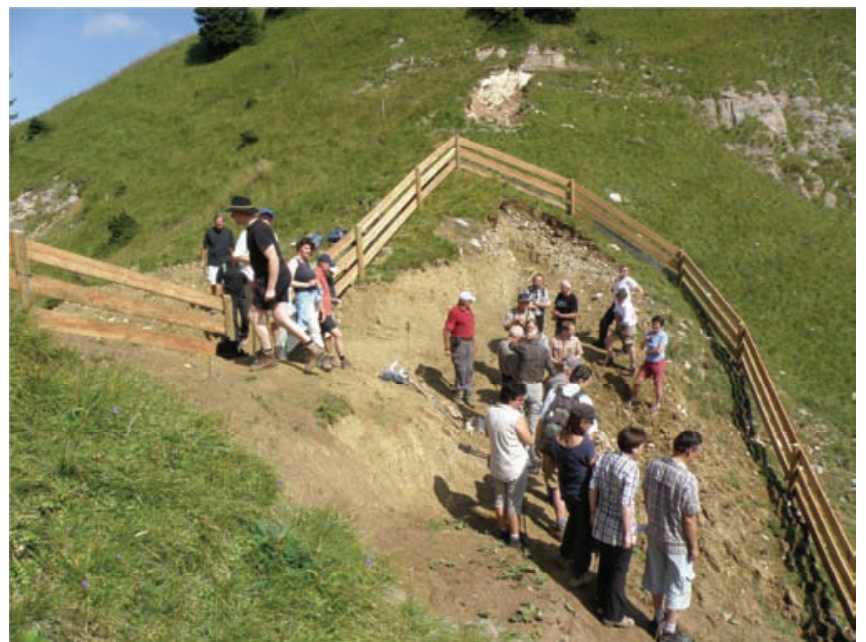

Figure 2. The Jurassic GSSP section on Kuhjoch looking north with Lower Jurassic carbonates behind. The section is excavated just on the east side of the crest of the ridge and protected by a wooden fence (photo Nicol Morton August 2011).

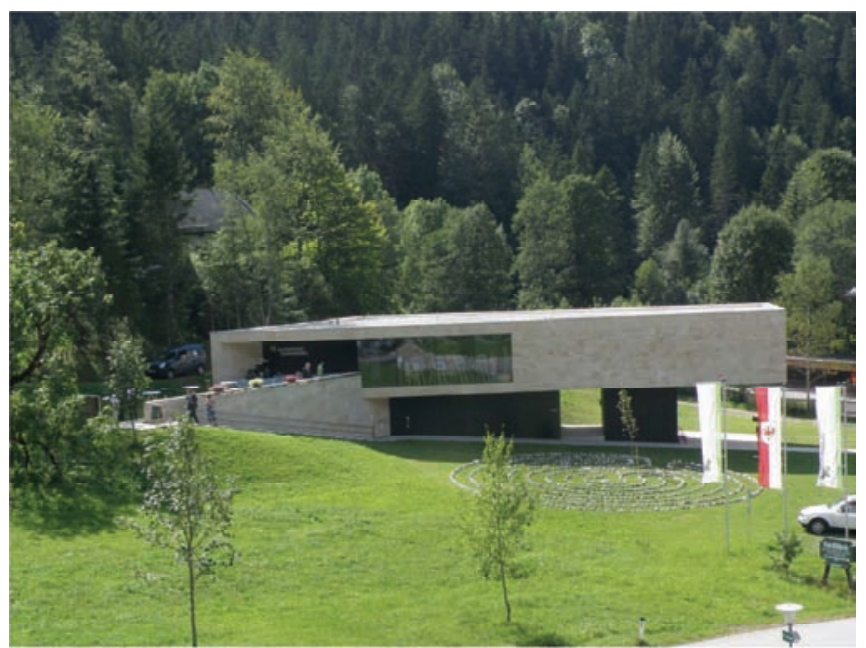

Figure 3. Naturparkhaus Hinteriss, museum of the natural history of the Karwendel Natural Park and conference hall, at Hinteriss, Tyrol, Austria (photo Nicol Morton August 2011).

Representatives of the International Commission on Stratigraphy, the International Subcommission on Jurassic Stratigraphy, the sponsoring organisations and the local community were present.

\section{Morning session at Kuhjoch site}

At the Kuhjoch locality the section was specially excavated and a protective fence erected (Fig. 2) with logistic support by helicopter given special permission by the Karwendel Park authorities. The new section is on the crest of the ridge, 5 to $10 \mathrm{~m}$ uphill and about $15 \mathrm{~m}$ east from the original section studied where, because of the steepness of the slope, permanent conservation would be impossible and it would have been very difficult to place a Golden Spike. Access for participants in the ceremony, including a television camera crew, was on foot! Two information panels by Sylvain Richoz and colleagues, with illustrations and text in German and English, were carried up the mountain to the site (see Figs. 4-7) and then back down to be displayed at the Naturparkhaus.

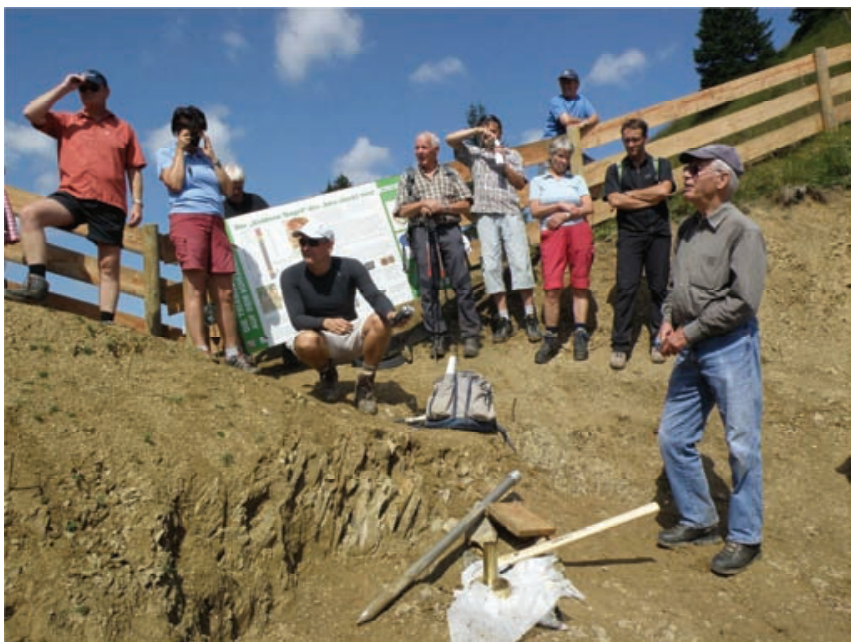

Figure 4. Prof. Axel von Hillebrandt (Berlin, Germany) explains the stratigraphy and palaeontology of the Jurassic GSSP section at Kuhjoch; note the waiting spike and "golden" cap (photo Nicol Morton August 2011).

Different authorities and also alpine farmers from the neighbouring valleys participated in the inauguration, at least 30 persons in total. Details of the section were described by two of the principal authors of the proposal, Axel von Hillebrandt, Berlin, Germany (Fig. 4) welcomed the participants and talked about the scientific history, the stratigraphy and palaeontology of the site, and why the Kuhjoch was proposed as GSSP for the Triassic-Jurassic boundary. Leopold Krystyn, Vienna, Austria (Fig. 5) explained the geology of the site

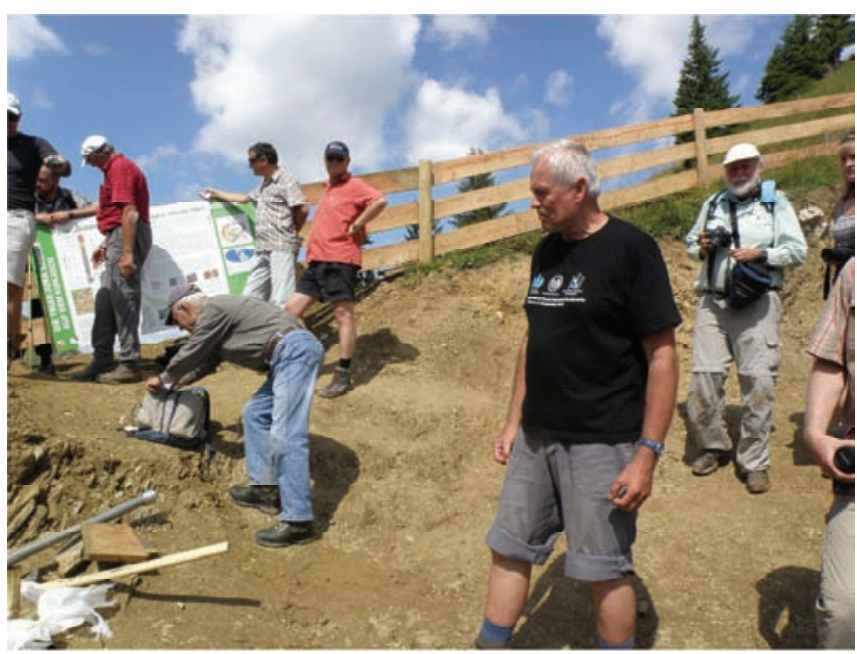

Figure 5. Prof. Leopold Krystyn (Vienna, Austria) takes over description and explanation of the section (photo Nicol Morton August 2011).

and its importance for understanding the events of this time. The third principal author, Wolfram Kuerschner, Utrecht, Netherlands, was unable to be present. A $1 \mathrm{~m}$ long spike was placed in position, hammered into the rock (Fig. 6) and the "golden" cap attached. The "seal of approval" was given by the authors and the representatives of ICS and ISJS (Fig. 7).

Finally, the success of a long procedure and the many years of work was celebrated with local schnapps and a bottle of "champagnetype" wine, appropriately a Cremant du Jura from Arbois, Département 


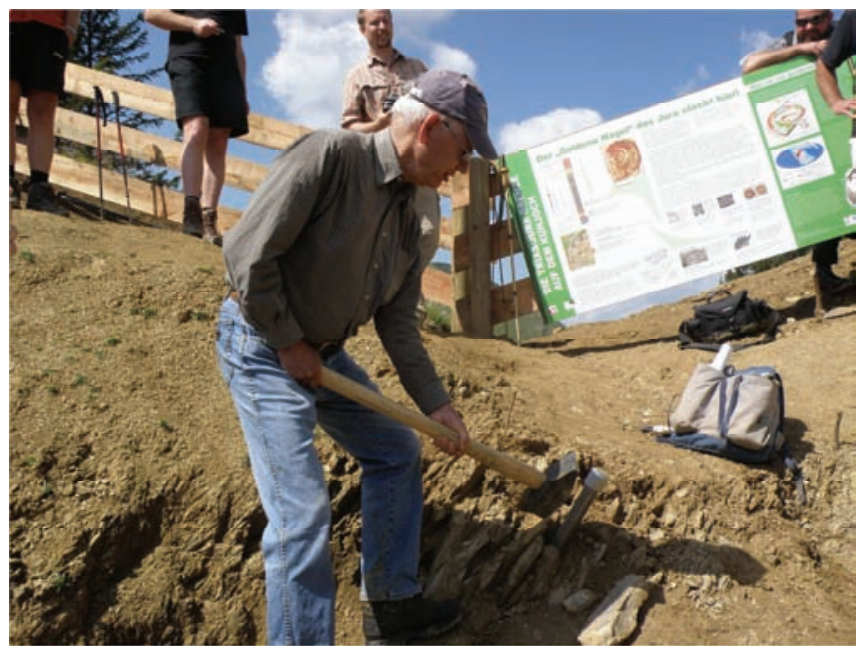

Figure 6. Prof. Axel von Hillebrandt inserting the spike marking the base of the Jurassic System, the GSSP. Note in the background one of the explanatory posters with the heading Der "Goldene Nägel" der Jura stekht hier! [The "Golden Spike" of the Jurassic is fixed here!] (photo Nicol Morton August 2011).

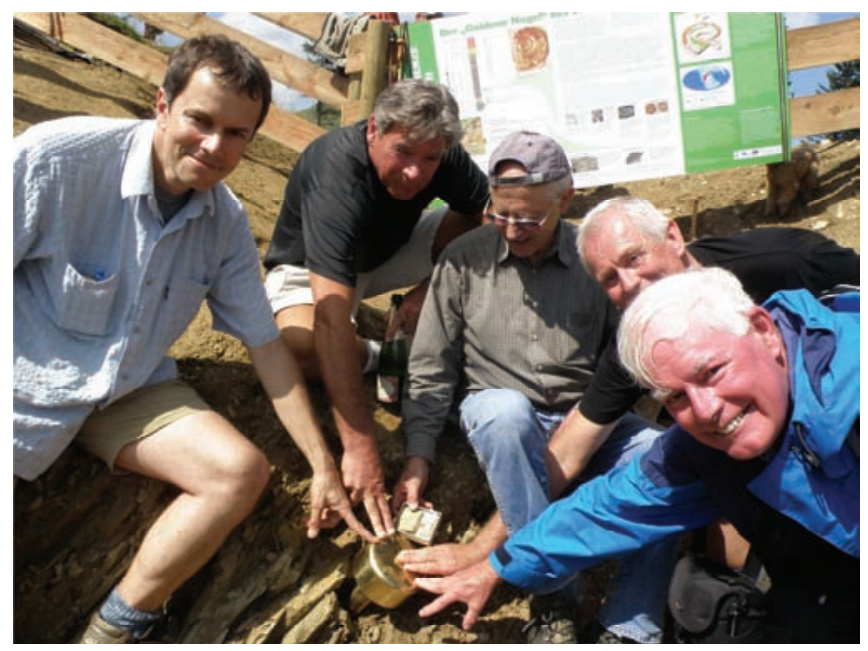

Figure 7. The "Golden Spike" marking the GSSP for the base of the Jurassic System receives the approval of (from left to right) Jozsef Palfy (Budapest, Hungary, Chairman of ISJS), Stan Finney (Long Beach, CA, USA, Chairman of ICS), Axel von Hillebrandt (Berlin, Germany, principal co-author of the GSSP proposal), Leo Krystyn (Vienna, Austria, principal co-author of the proposal) and Nicol Morton Vogüé, France, former Chairman of ISJS) (photo taken for Nicol Morton August 2011).

du Jura, France, made from vines grown on Triassic/Jurassic boundary strata (Fig. 8).

\section{Afternoon session at Naturparkhaus Hinteriss}

After a picnic lunch in the field, participants gathered at the Karwendel Naturparkhaus in Hinteriss for the official dedication and celebration (Fig.9). An extract of the television video made during the morning was shown. The session was chaired by Hermann Sonntag, Karwendel Natural Park, who introduced the following speakers and topics:

1. Greetings and congratulations to participants presented by Prof.

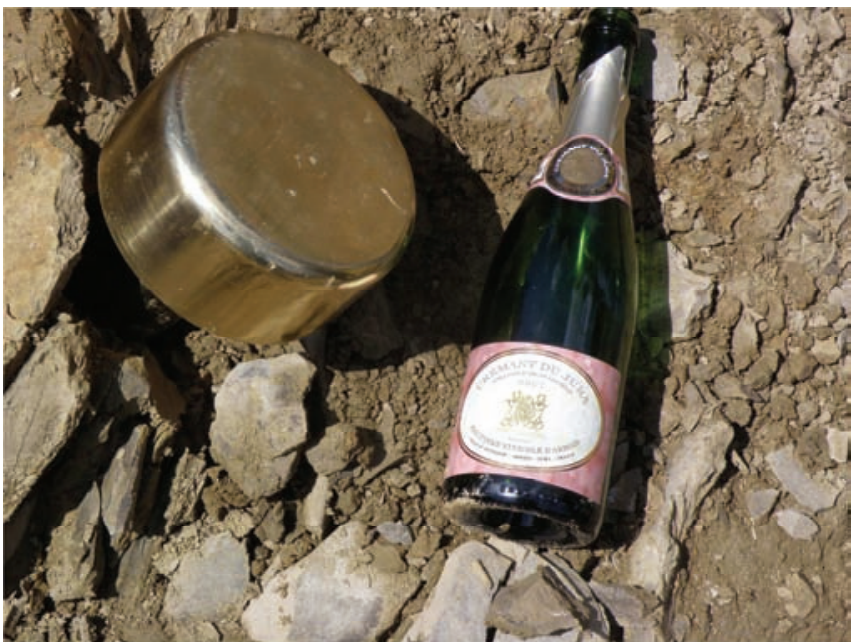

Figure 8. The success of the long procedure of establishing the selected Jurassic GSSP was celebrated on site with local schnapps and a Cremant du Jura, a champagne-type wine from Arbois (Jura), France from vines grown on Triassic/Jurassic boundary strata. The empty bottle was NOT left on site! (photo Nicol Morton August 2011).

Dr. Karlheinz Töchterle, Federal Minister for Science and Research of Austria;

2. An appreciation of the GSSP in the context of the role of the Park by Burgermeister Klaus Gasteiger as representative of the Governor of the State of Tyrol;

3. The role of GSSPs and the importance of the Jurassic GSSP in the geological time-scale and understanding Earth history by Prof. Stanley C. Finney, Chairman of the International Commission on Stratigraphy;

4. An appreciation of the work of those involved in the GSSP proposals for the Jurassic and the importance of communication with a wider public by Prof. Jozsef Palfy, Chairman of the International Subcommission on Jurassic Stratigraphy;

5. The Jurassic GSSP and its geological context in relationship to geological research in Austria by Prof. Werner E. Piller, President of the Austrian National Committee for Earth Sciences.

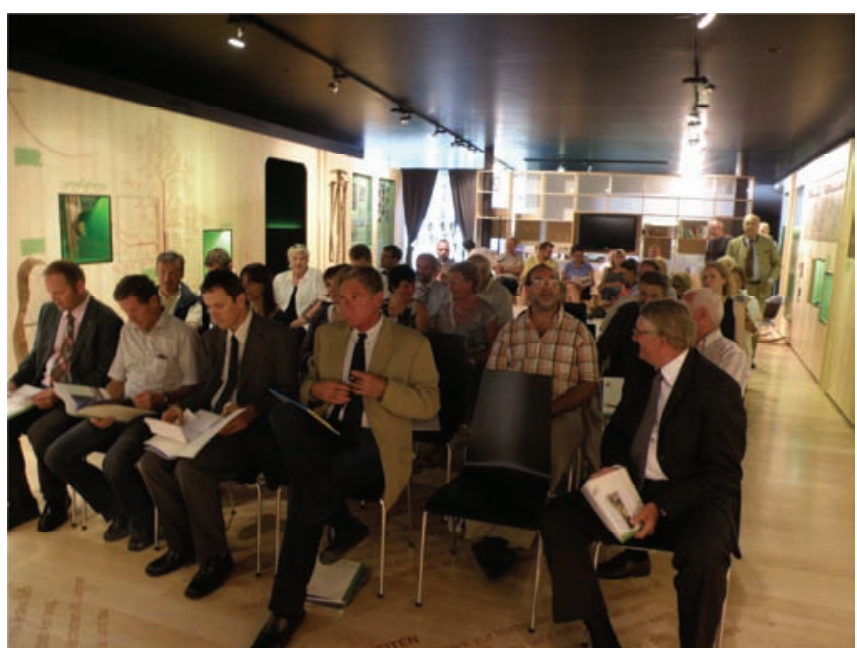

Figure 9. The official inauguration of the Jurassic GSSP took place in the Naturparkhaus Hinteriss, with speakers (front row left to right) Prof. Dr. Karlheinz Töchterle, Klaus Steiger, Jozsef Palfy, Stan Finney and Werner Piller (photo Nicol Morton August 2011). 
After a buffet on the terrace, during which the explanatory posters on the GSSP were displayed, a public lecture was given in the evening by Prof. Rainer Brandner (Universität Innsbruck) on "Die Trias-Jura Grenze und andere Massenaussterbeereignisse" [The Triassic-Jurassic boundary and other mass extinctions].

The participants in the inauguration of the Jurassic GSSP included Austrian geologists working on a diverse range of topics and many local officials and landowners. There was a very evident sense of pride in this inauguration of the first Austrian GSSP.

\section{Conclusions}

Over 20 years of hard work by a large number of scientists, many more than those listed as the final authors of proposals, have been brought to a successful conclusion with the inauguration of the GSSP defining the base of the Jurassic System in the Kuhjoch section, Karwendel Natural Park in Austria. Uncertainties over the precise position of the Triassic/Jurassic boundary have been resolved. The problems of analysing and understanding one of the Earth's major extinction and evolutionary events now depend on successful correlation. Several methods for this can be applied on the basis of the stratigraphical data provided and applied to non-marine as well as marine strata.

\section{Acknowledgements}

This conclusion could not have been achieved without the enormous commitment of a large number of specialists in many fields.
It has been a great multinational and multidisciplinary effort, not only by those whose hard work over many years brought the six proposals to fruition, but also to an even larger number who took responsibility for making the final decision as to which one should be selected as GSSP and forwarded to ISJS, then to ICS and IUGS. The international geological community owes them all a great debt of gratitude. On a personal note I am grateful to many colleagues for their support and suggestions, and particularly to Prof. Axel von Hillebrandt for his suggestions on an earlier draft of this paper.

\section{References}

Arkell, W.J., 1933, The Jurassic System in Great Britain. Clarendon Press, Oxford.

Arkell, W.J., 1956, Jurassic Geology of the World. Oliver \& Boyd, Edinburgh

Bown, P., Morton, N. and Lees, J. (eds.) 2007, International Subcommission on Jurassic Stratigraphy Newsletter 34/1 July 2007, 69pp.

Hesselbo, S.P., Mcroberts, C.A. and Palfy, J, 2007, 'Triassic-Jurassic boundary events: Problems, progress, possibilities. Palaeogeography, Palaeoclimatology, Palaeoecology, v. 244, pp. 1-10.

Hillebrandt, A.V. and Krystyn, L., 2009, On the oldest Jurassic ammonites of Europe (Northern Calcareous Alps, Austria) and their global significance: Neues Jahrbuch Geologie und Paläontologie Abh., v. 253/2-3, pp.163-195.

Morton, N. and Hesselbo, S. (eds.) 2008, International Subcommission on Jurassic Stratigraphy Newsletter 35/1 December 2008 74pp. 